\title{
SISTEM INFORMASI PENGOLAHAN DATA PERKARA PERDATA PADA PENGADILAN NEGERI SAMARINDA BERBASIS JARINGAN
}

\author{
Ahmad Rofiq Hakim ${ }^{1)}$, Amelia Yusnita ${ }^{2)}$, Hariyadi ${ }^{3)}$ \\ ${ }^{1,2}$ Sistem Informasi, Stmik Widya Cipta Dharma \\ ${ }^{3}$ Sistem Informasi, Stmik Widya Cipta Dharma \\ 1,2,3 Jl. Prof. M. Yamin No. 25, Samarinda, 75123 \\ E-mail :rofiq_93@yahoo.com ${ }^{1)}$, lia_amelia@yahoo.co.id ${ }^{2}$, yadispedd13@yahoo.com ${ }^{3)}$
}

\begin{abstract}
ABSTRAK
Pengadilan Negeri Samarinda merupakan . Sampai saat ini pengolahan data persediaan suku cadang mobil masih dilakukan dengan cara manual dan menggunakan perangkat komputer dengan pengolahan data laporan menggunakan aplikasi Ms. Excel.

Metode yang digunakan pada penelitian ini meliputi metode pengumpulan data yaitu penelitian lapangan dan penelitian kepustakaan.Sedangkan metode pengembangan sistem yang digunakan dalam pengembangan sistem informasi ini adalah metode waterfall terdiri dari perencanaan sistem, analisis sistem, desain sistem, penerapan sistem, dan perawatan sistem. Dengan bantuan tools seperti flow of document (FOD), data flow document (DFD), hierarchy input proses output (HIPO), struktur database dan desain input output program.

Penelitian ini menghasilkan suatu Sistem Informasi Pengolahan Data Perkara Perdata Pada Pengadilan Negeri Samarinda berbasis Jaringan ini yang dapat diakses oleh bagian administrasi dan staff bagian perdata.Aktivitas yang dapat dilakukan dengan sistem ini meliputi proses pengolahan Data pengolahan perkara perdata berupa input penggugat, hakim, panitera, pemohon, proses gugatan, proses banding, proses kasasi dan proses peninjauan kembali serta pelaporannya.

Sistem ini dikembangkan dengan pemrograman Microsoft Visual Basic 6.0 dan databasenya dibangun dengan menggunakan MySQL, karena kebutuhan yang selalu berkembang, maka kekurangan pada sistem ini nantinya dapat diperbaiki pada pengembangan sistem selanjutnya.
\end{abstract}

Kata Kunci : Sistem, Informasi, Pengolahan Data Perkara Perdata

\section{PENDAHULUAN}

Penggunaan sarana komputer dewasa ini merupakan salah satu terpenting dalam menyelesaikan suatu pekerjaan pengolahan data di berbagai bidang pekerjaan, baik itu kantor pemerintahan, kantor-kantor milik swasta, usaha kecil dan lain sebagainya. Hal ini tidak dapat dipungkiri lagi sebab tanpa menggunakan komputer dalam menyelesaikan suatu pekerjaan pengolahan data akan relatif dan memerlukan waktu yang lama dalam penyelesaiannya.

Didalam penggunaan Microsoft excel dan Microsoft word dalam mengolah data perkara perdata kurang membantu karena transaksi yang terjadi setiap harinya cukup banyak. Selain itu pelaporan sering tidak sesuai dan banyak yang tidak terdata.

Melihat kondisi diatas penulis membuat Sistem Informasi Pengolahan Data Perkara Perdata Berbasis Jaringan Pada Pengadilan Negeri Samarinda dengan tujuan agar dapat mendukung dalam proses perkara pidana dan perdata serta mendukung keputusan oleh pihak Pengadilan Negeri Samarinda dalam memberikan informasi yang lengkap, serta dapat dengan cepat di rasakan demi meningkatnya SDM pada Pengadilan Negeri Samarinda. Dengan adanya Sistem Informasi Pengolahan Data Perkara Perdata Berbasis Jaringan Pada Pengadilan Negeri Samarinda ini dapat membantu dalam mengelola data keputusan perakara perdata serta pembuatan laporan dengan tepat dan mudah dimengerti guna mencapai tujuan yang ditetapkan.

\section{RUANG LINGKUP PENELITIAN}

Dalam penelitian ini permasalahan mencakup :

1. Cakupan Masalah

Terdapat beberapa kendala dalam hal pengelolaan data perkara perdata pada Pengadilan Negeri Samarinda, dan tidak terhubungnya antar komputer, hal tersebut membutuhkan waktu yang cukup lama. Kesulitankesulitan tersebut membuat pekerjaan jadi tidak hemat waktu.

2. Batsan-batasan penelitian Inputan data:

1). Input data penggugat

2.).Input data hakim

3). Input data panitera

4). Input data permohonan

Proses :

1). Gugatan

2). Banding

3). Kasasi 

4). Peninjauan Kembali
5). Eksekusi
Laporan:
1). Daftar Penggugat
2). Daftar Hakim
3). Laporan Persidangan

\section{BAHAN DAN METODE}

\subsection{Penjelasan Bahan}

Sistem merupakan kumpulan elemen yang saling berkaitan yang bertanggungjawab memproses masukan (input) sehingga menghasilkan keluaran (output) (Kusrini, 2007)

MySQL tergolong sebagai DBMS (Database Management System). Perangkat lunak ini bermanfaat untuk mengelola data dengan cara yang sangat fleksibel dan cepat. (Kadir, 2009)

Visual Basic selain disebut sebagai bahasa pemrograman (Language Program), juga sering disebut sebagai sarana (Tool) untuk menghasilkan programprogram aplikasi berbasis Windows. (Yuswanto, 2003)

\subsection{Metode}

Model Air Terjun (Waterfall) adalah untuk membantu mengatasi kerumitan yang terjadi akibat proyek-proyek pengembangan perangkat lunak(Simarmata, 2010).

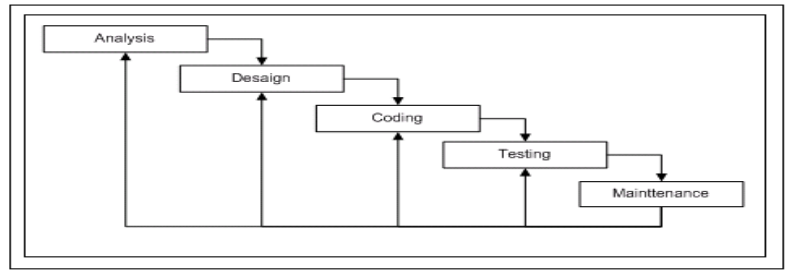

Gambar 1. Model Pengembangan Air Terjun

\section{RANCANGAN SISTEM/APLIKASI}

Dari Flow Of Document yang sedang berjalan dapat dilihat pada (gambar 4.2) bahwa Sistem Informasi Pengolahan Data Perkara Perdata dimulai dari entitaspenggugatmemberikan dokumen data penggugat ke entitas adminstrasi yang kemudian dokumen tersebut diproses secara manual sehingga menghasilkan daftar penggugat. Pada entitas hakim memberikan data hakim ke entitas administrasi untuk selanjutnya di proses secara manual sehingga menghasilkan daftar hakim. Proses persidangan terdapat dientitas administrasi yang mendapat aliran data dari dokumen daftar penggugat dan dokumen daftar hakim yang kemudian dilakukan proses pembuatan laporan. Laporan ada 3 (tiga) yaitu daftar penggugat, daftar hakim dan laporan persidangan. Proses selesai pada entitas ketua.

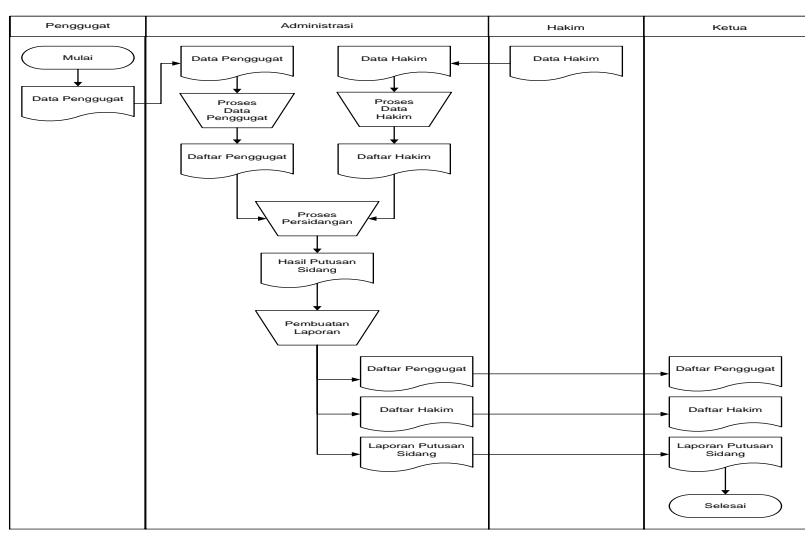

\section{Gambar 2. Flow Of Document ( FOD ) Yang Berjalan}

Dari gambar Flow Of Document sistem yang diusulkan dapat dilihat pada (gambar 4.3) bahwa Sistem Informasi Pengolahan Data Perkara Perdata dimulai dari entitas penggugat memberikan dokumen data penggugat ke entitas administrasi yang kemudian di input lewat keyboard lalu diproses secara komputerisasi yang tersimpan dalam database penggugat sehingga menghasilkan dokumen daftar penggugat.Pada entitas hakim memberikan dokumen data hakim ke entitas administrasi yang kemudian diinput lewat keyboard lalu diproses secara komputerisasi yang datanya tersimpan dalam database hakim sehingga menghasilkan dokumen daftar hakim. Pada entitas administrasi juga terdapat dokumen panitera yang kemudian diinput lewat keyboard dan diproses secara komputerisasi yang datanya disimpan dalam database panitera sehingga menghasilkan daftar panitera. Proses persidangan dilakukan pada entitas administrasi yang mendapat aliran data dari database penggugat dan database hakim diproses secara komputerisasi yang datanya tersimpan dalam database gugatan. Proses banding, proses kasasi, proses peninjauan kembali dan proses ekesekusi mendapat aliran data dari database gugatan yang diproses secara komputerisasi yang tersimpan kedalam masing-masing database banding, database kasasi, database peninjauan kembali dan database eksekusi. Pada entitas administrasi juga terdapat data permohonan yang kemudian diinput lewat keyboard dan diproses secara komputisasi yang datanya disimpan dalam database permohonan. Proses pembuatan laporan mendapat aliran dari database hakim, database penggugat, gugatan, banding, kasasi, peninjauan kembali dan eksekusi yang menghasilkan 3 (tiga) laporan yaitu laporan daftar penggugat, laporan daftar hakim dan laporan persidangan yang kemudian dialirkan ke entitas ketua.Proses berakhir pada entitas ketua. 


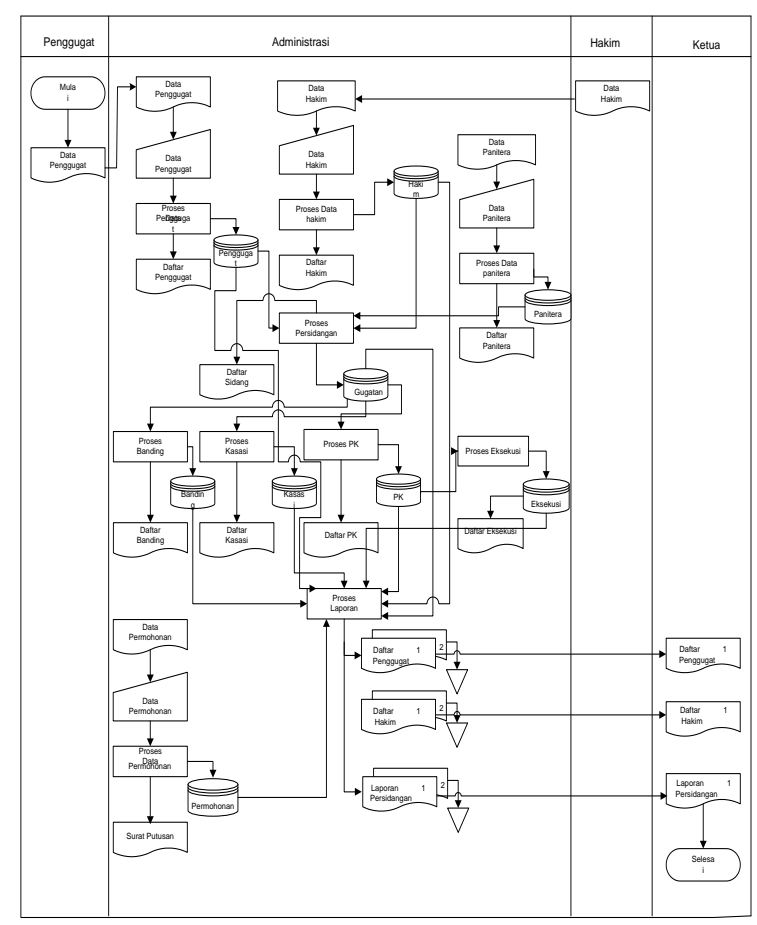

Gambar 3.FOD Yang Diusulkan

Dari Context Diagram terdapat empat kesatuan luar (eksternal entity) yaitu bagian Administrasi memberikan data gugatan, data panitera, data permohonan, data banding, data kasasi, data peninjauan kembali dan data eksekusi ke sistem. Entitas penggugat memberikan data penggugat ke sistem. Entitas hakim memberikan data hakim ke sistem. Entitas ketua memperoleh daftar penggugat, daftar hakim dan laporan persidangan dari sistem.

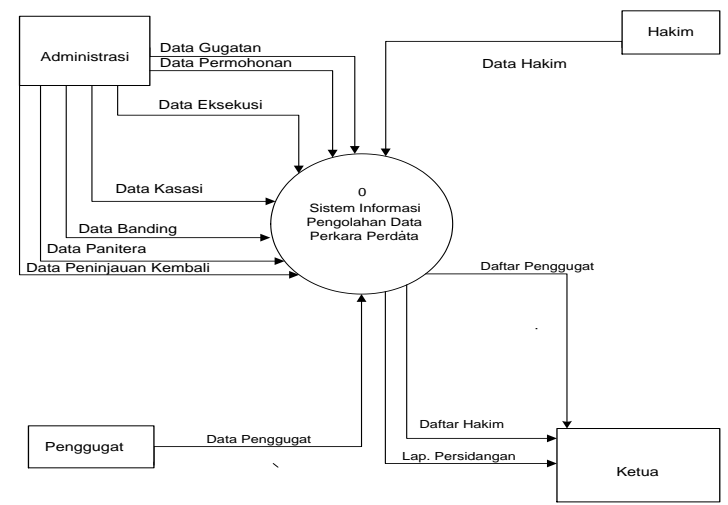

Gambar 4.Context Diagram

DFD pada Entitas Penggugat menjadi sumber data penggugat yang datanya disimpan dalam data store penggugat yang kemudian dialirkan ke proses eksekusi dan proses pembuatan laporan. Entitas hakim menjadi sumber data hakim yang datanya disimpan dalam data store hakim yang kemudian dialirkan ke proses eksekusi dan proses pembuatan laporan. Entitas.administrasi menjadi sumber data gugatan, data banding, data kasasi, data peninjauan kembali, data permohonan yang datanya disimpan dalam data store gugatan, data store banding, data store kasasi, data store peninjauan kembalidan data store permohonan yang kemudian dialirkan ke proses eksekusi dan proses pembuatan laporan. Proses pembuatan laporan menghasilkan tiga yaitu daftar penggugat, daftar hakim dan laporan persidangan yang kemudian dialirkan ke entitas ketua.

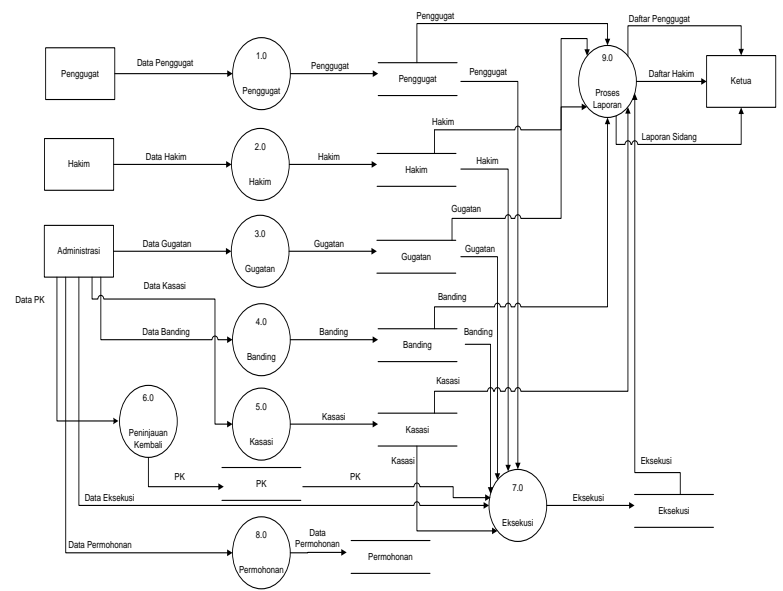

Gambar 5. Data Flow Diagram (DFD) Level0

.DFD level 1 dimulai dari data store penggugat memberikan aliran data penggugat ke proses laporan daftar penggugat yang kemudian dialirkan ke entitas ketua. Selain itu data store penggugat juga mengalirkan data ke data store gugatan, data store banding, data store kasasi, data store peninjauan kembali dan data store eksekusi sehingga menghasilkan data hasil persidangan dan dialirkan ke proses laporan persidangan serta dialirkan ke entitas ketua. Data store hakim mengalirkan data hakim ke proses laporan daftar hakim dan di alirkan ke entitas ketua.

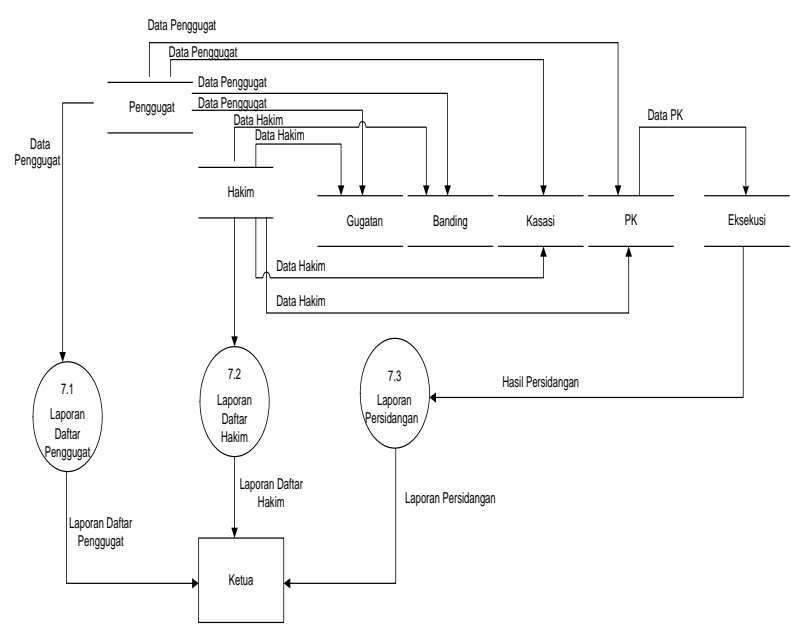

Gambar 6.Data Flow Diagram (DFD) Level 1

Dari Hierarchy Plus Input Proces Output (HIPO) Sistem Informasi Pengolahan Data Perkara Perdata dapat terlihat bahwa sistem ini terdiri dari tujuh proses utama yaitu penggugat, hakim, gugatan, banding, 
kasasi,peninjauan kembali, permohonan, eksekusi, dan proses pembuatan laporan. Proses pembuatan laporan yang terdiri dari laporan daftar penggugat, laporan daftar hakim dan laporan persidangan.

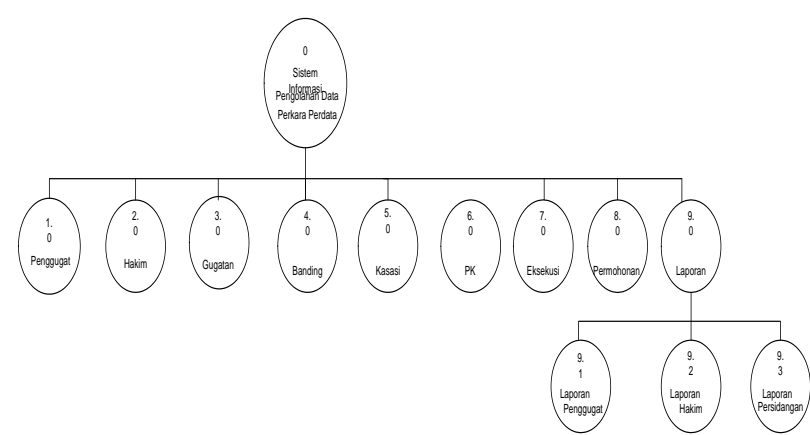

Gambar 7 HIPO(Hirarchy Plus Input-Proses-output)

5.

\section{MPLEMENTASI}

5.1

ampilan Form Input data penggugat

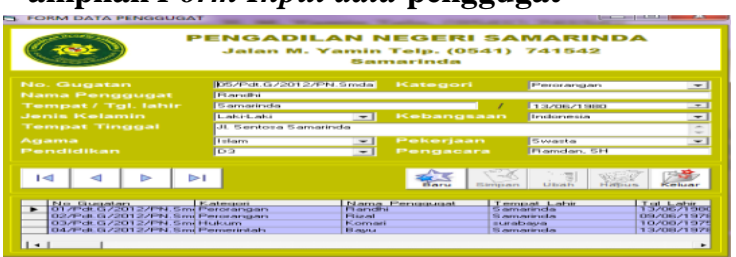

Gambar 8.Form Input Data penggugat

merupakan form untuk menginputkan data penggugat. Data yang akan diinput berisikan No. gugatan, kategori,nama penggugat, tempat / tgl.lahir, jenis kelamin, tempat tinggal, agama dan pendidikan. Dalam tampilan input data ini terdapat 4 (empat) tombol navigasi dan 5 (lima) tombol lainnya yaitu tombol baru, simpan, edit, hapus dan tutup.

jika pengguna (user) menekan tombol baru maka pengguna (user) dapat meginputkan data yang baru. Jika pengguna (user) menekan tombol simpan maka data penggugat yang telah di input akan tersimpan. Jika pengguna (user) menekan tombol edit maka kesalahan data penggugat yang telah di input tadi dapat diperbaiki.Jika pengguna (user) menekan tombol hapus maka data penggugat yang salah dapat dihapus. Apabila pengguna(user) menekan tombol tutup, maka proses program akan kembali ke menu utama.

\subsection{Tampilan Form Input Data Hakim}

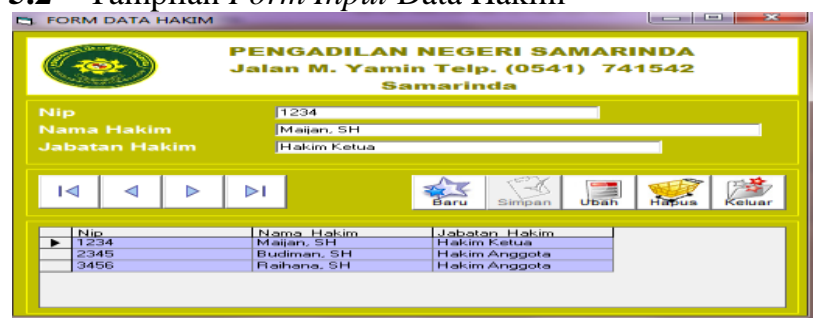

\section{Gambar 9.Form Input Data Hakim}

merupakan form untuk menginputkan data hakim. Data yang akan diinput berisikan nip, nama hakim dan jabatan hakim. Dalam tampilan input data ini terdapat 4 (empat) tombol navigasi dan 5 (lima) tombol lainnya yaitu tombol baru, simpan, edit, hapus dan tutup.Jika pengguna (user) menekan tombol baru maka pengguna (user) dapat meginputkan data yang baru. Jika pengguna (user) menekan tombol simpan maka data hakim yang telah di input akan tersimpan. Jika pengguna (user) menekan tombol edit maka kesalahan data hakim yang telah di input tadi dapat diperbaiki.Jika pengguna (user) menekan tombol hapus maka data hakim yang salah dapat dihapus. Apabila pengguna(user) menekan tombol tutup, maka proses program akan kembali ke menu utama.

\subsection{Tampilan Form Input Data panitera}

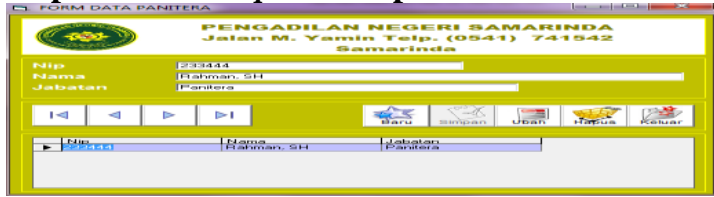

TGambar 10.Form Input Data Panitera

merupakan form untuk menginputkan data panitera. Data yang akan diinput berisikan nip, nama dan jabatan. Dalam tampilan input data ini terdapat 4 (empat) tombol navigasi dan 5 (lima) tombol lainnya yaitu tombol baru, simpan, edit, hapus dan tutup.

Jika pengguna (user) menekan tombol baru maka pengguna (user) dapat meginputkan data yang baru. Jika pengguna (user) menekan tombol simpan maka data panitera yang telah di input akan tersimpan. Jika pengguna (user) menekan tombol edit maka kesalahan data panitera yang telah di input tadi dapat diperbaiki.Jika pengguna (user) menekan tombol hapus maka data panitera yang salah dapat dihapus. Apabila pengguna (user) menekan tombol tutup, maka proses program akan kembali ke menu utama.

\subsection{Tampilan Form Input Permohonan}

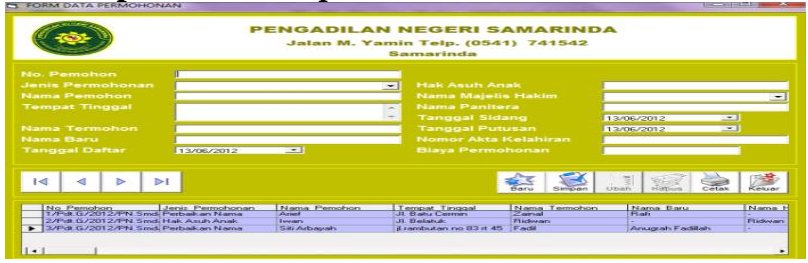

Gambar 11.Form Input Data Permohonan 


\subsection{Form Transaksi Gugatan}

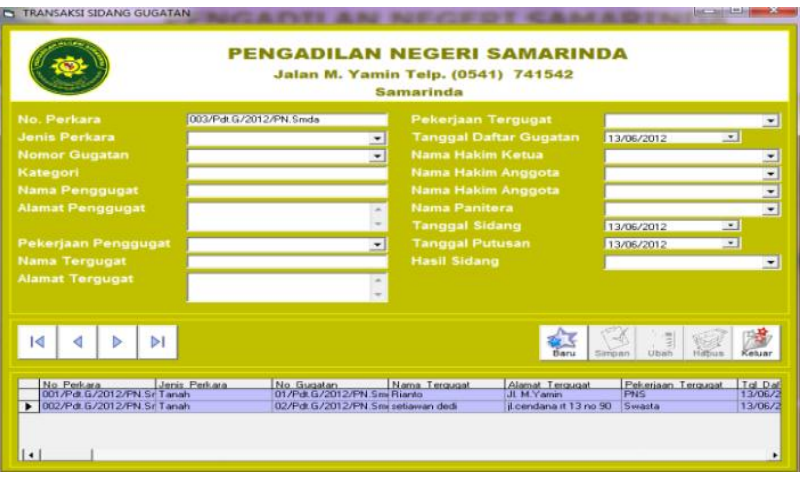

Gambar 12 Form Transaksi Gugatan

merupakan form untuk transaksi sidang gugatan. Data yang akan diinput berisikan no. perkara, jenis perkara, nomor gugatan,kategori, nama penggugat, alamat tergugat, pekerjaan tergugat, tanggal daftar gugatan, nama hakim ketua, nama hakim anggota, nama hakim anggota, nama panitera, tanggal sidang, tanggal putusan dan hasil sidang. Dalam tampilan input data ini terdapat 4 (empat) tombol navigasi dan 5 (lima) tombol lainnya yaitu tombol baru, simpan, ubah, hapus dan keluar.

Jika pengguna (user) menekan tombol baru maka pengguna (user) dapat meginputkan data yang baru. Jika pengguna (user) menekan tombol simpan maka data transaksi sidang gugatan yang telah di input akan tersimpan. Jika pengguna (user) menekan tombol ubah maka kesalahan data transaksi sidang gugatan yang telah di input tadi dapat diperbaiki.Jika pengguna (user) menekan tombol hapus maka data transaksi sidang gugatan yang salah dapat dihapus. Apabila pengguna(user) menekan tombol keluar, maka proses program akan kembali ke menu utama.

\subsection{Form Transaksi Banding}

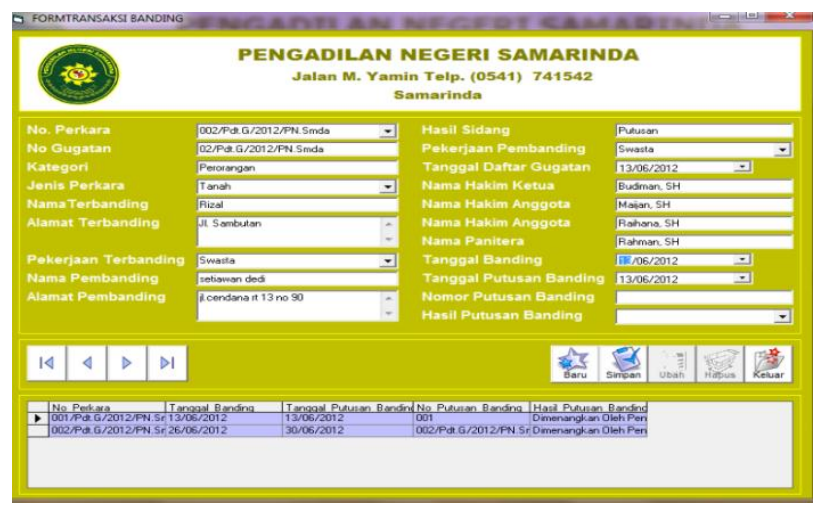

Gambar 13 Form Transaksi Banding

merupakan form untuk menginputkan transaksi banding. Pada saat data diinputkan maka no perkaraakan muncul secara otomatis mengikuti nomor terakhir yang telah diinputkan. Dimana inputan datanya berisikan no perkara, no gugatan, kategori, hasil sidang, jenis perkara, kode nama penggugat, alamat tergugat, pekerjaan tergugat, tanggal daftar gugatan, nama hakim ketua, nama hakim anggota, nama hakim anggota, nama panitera, tanggal banding, tanggal putusan banding, nomor putusan banding dan hasil putusan banding.Apabila user ingin menginputkan data baru klik tombol baru dan isikan semua datanya kemudian tekan tombol simpan.Apabila user ingin mengubah data klik tombol ubah kemudian ubah data tersebut dan klik tombol simpan.Apabila user ingin menghapus klik tombol hapus.Apabila user ingin keluar dari program klik tombol keluar.

\subsection{Form Transaksi Kasasi}

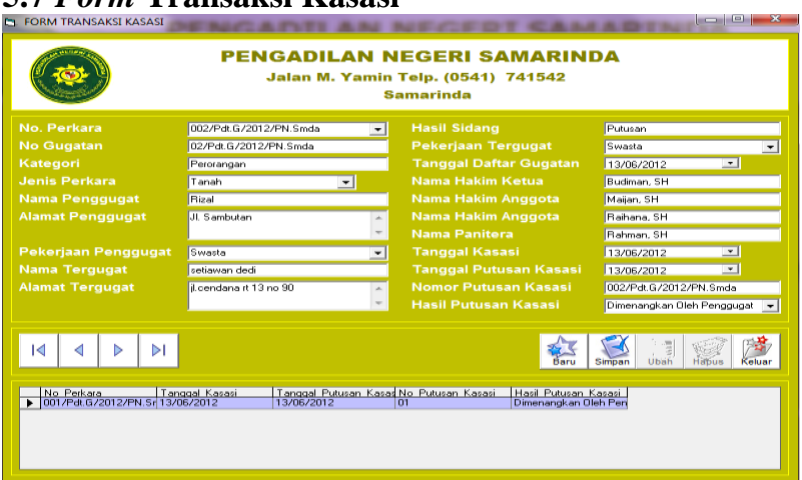

Gambar 14 Form transaksi kasasi

merupakan form untuk menginputkan transaksi kasasi. Pada saat data diinputkan maka no perkaraakan muncul secara otomatis mengikuti nomor terakhir yang telah diinputkan. Dimana inputan datanya berisikan no perkara, no gugatan, kategori, hasil sidang, jenis perkara, nama penggugat, alamat penggugat, pekerjaan penggugat, nama tergugat, alamat tergugat, pekerjaan tergugat, tanggal dan daftar gugatan, nama hakim ketua, nama hakim anggota, nama hakim anggota, nama panitera, tanggal kasasi, tanggal putusan kasasi, nomor putusan kasasi dan hasil putusan kasasi. Apabila user ingin menginputkan data baru klik tombol baru dan isikan semua datanya kemudian tekan tombol simpan.Apabila user ingin mengubah data klik tombol ubah kemudian ubah data tersebut dan klik tombol simpan.Apabila user ingin menghapus klik tombol hapus.Apabila user ingin keluar dari program klik tombol keluar.

\subsection{Form Transaksi Peninjauan Kembali}

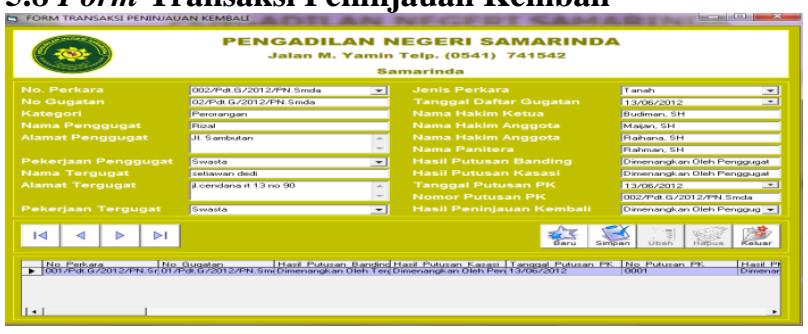

\section{Gambar 15 Form Transaksi Peninjauan Kembali}

merupakan form untuk menginputkan transaksi peninjauan kembali. Pada saat data diinputkan maka no perkara akan muncul secara otomatis mengikuti nomor terakhir yang telah diinputkan. Dimana inputan datanya berisikan no. perkara, jenis perkara, nama penggugat, 
alamat penggugat, pekerjaan penggugat, nama tergugat, alamat tergugat, pekerjaan tergugat, tanggal daftar gugatan, nama hakim ketua, nama hakim anggota, nama hakim anggota, nama panitera, hasil putusan banding, hasil putusan kasasi, tanggal putusan pk, nomor putusan pk dan hasil peninjauan kembali. Apabila user ingin menginputkan data baru klik tombol baru dan isikan semua datanya kemudian tekan tombol simpan.Apabila user ingin mengubah data klik tombol ubah kemudian ubah data tersebut dan klik tombol simpan.Apabila user ingin menghapus klik tombol hapus.Apabila user ingin keluar dari program klik tombol keluar.

\subsection{Form Transaksi Eksekusi}

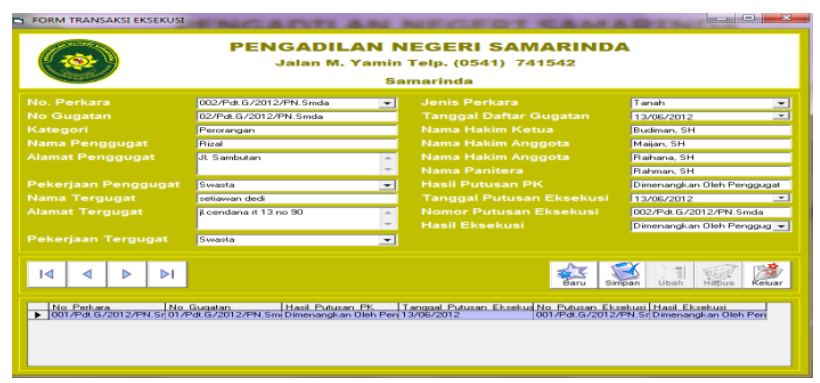

\section{Gambar 16 Form Transaksi Eksekusi}

merupakan tampilan transaksi eksekusi dengan informasi yang diberikan terdiri dari berisikan no. perkara, jenis perkara, nama penggugat, alamat penggugat, pekerjaan penggugat, nama tergugat, alamat tergugat, pekerjaan tergugat, tanggal daftar gugatan, nama hakim ketua, nama hakim anggota, nama hakim anggota, nama panitera, hasil putusan pk, tanggal putusan eksekusi, nomor putusan eksekusi dan hasil eksekusi.

\subsection{Laporan Daftar Penggugat}

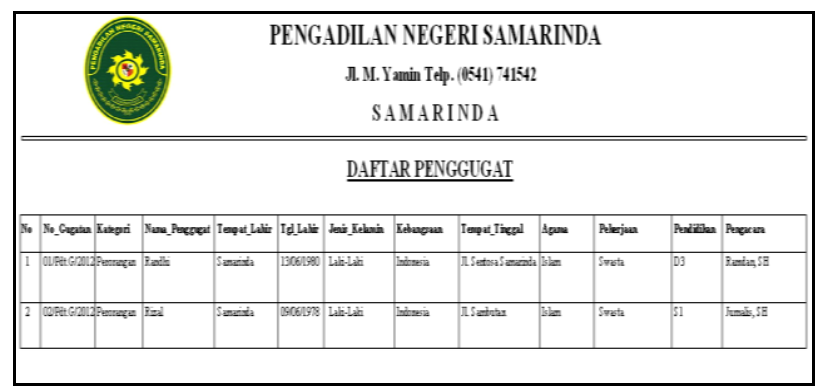

Gambar 17 Laporan Daftar Penggugat merupakan tampilan daftar penggugat yang terdiri dari no. gugatan, kategori,nama penggugat, tempat lahir, tanggal lahir, jenis kelamin, kebangsaan, tempat tinggal, agama, pekerjaan, pendidikan dan pengacara.

\subsection{Laporan Daftar Hakim}

\begin{tabular}{|c|c|c|c|}
\hline & & \multicolumn{2}{|c|}{$\begin{array}{l}\text { PENGADILAN NEGERI SAMARINDA } \\
\text { ग. M. Y amin Telp. (0541) } 741542 \\
\text { S A M A R I N D A }\end{array}$} \\
\hline & & \multicolumn{2}{|c|}{ DAFTAR HAKIM } \\
\hline No & Nip & Nama_Halim & Jah atan_Hakim \\
\hline 1 & 1234 & Maijen, SH & Hakim Ketua \\
\hline 2 & 2345 & Budiman, SH & Hakim Anggota \\
\hline \begin{tabular}{|l|}
3 \\
\end{tabular} & 3456 & Raihana, $\mathrm{SH}$ & Hakim Anggota \\
\hline
\end{tabular}

Gambar 18 Laporan Daftar Hakim

merupakan tampilan daftar hakim yang terdiri dari nip, nama hakim dan jabatan hakim. Informasi ini diperoleh dari input data hakim.

\subsection{Laporan Perkara Perdata}

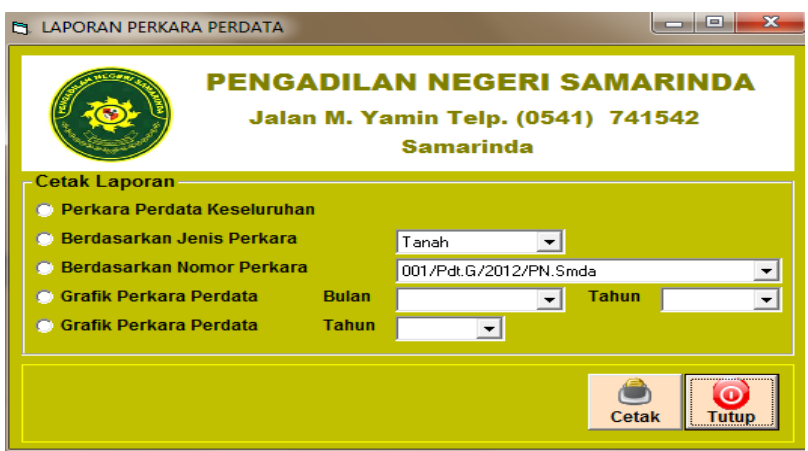

Gambar 19 Form Laproran perkara perdata

merupakan tampilan laporan perkara perdata yang didalam form ini menampilkan laporan perkara perdata keseluruhan, laporan data perkara perdata berdasarkan jenis perkara, laporan perkara perdata berdasarkan nomor perkara, laporan grafik perkara perdata perbulan dan laporan grafik perkara perdata pertahun. Apabila user ingin melihat tampilan perkara perdata keseluruhan klik cetak laporan perkara perdata keseluruhan dan klik tombol cetak maka akan tampil seperti gambar dibawah ini.

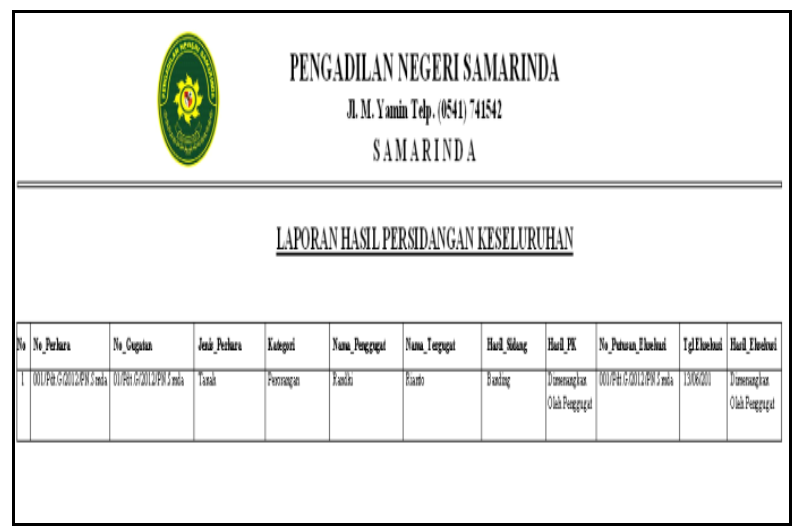

Gambar 20 Laporan Perkara Sidang Keseluruhan Apabila user ingin melihat tampilan perkara perdata berdasarkan jenis perkara klik cetak berdasarkan jenis perkara dan klik tombol cetak maka akan tampil seperti gambar dibawah ini. 


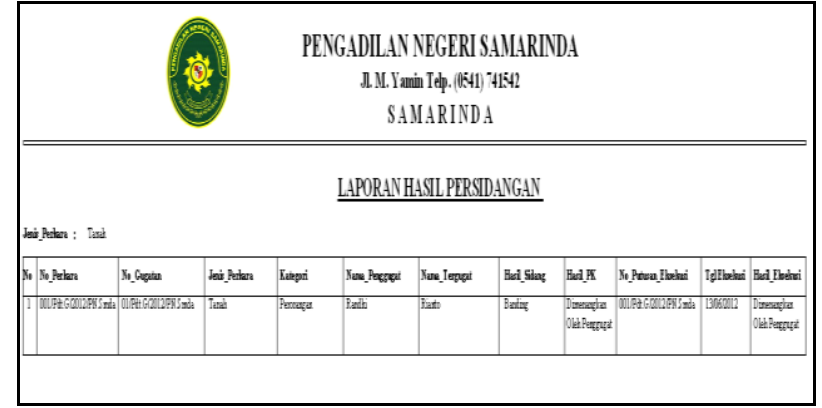

Gambar 21 Laporan Berdasarakan Jenis Perkara

Apabila user ingin melihat tampilan perkara perdata berdasarkan nomor perkara klik cetak berdasarkan nomor perkara dan klik tombol cetak maka akan tampil seperti gambar dibawah ini.

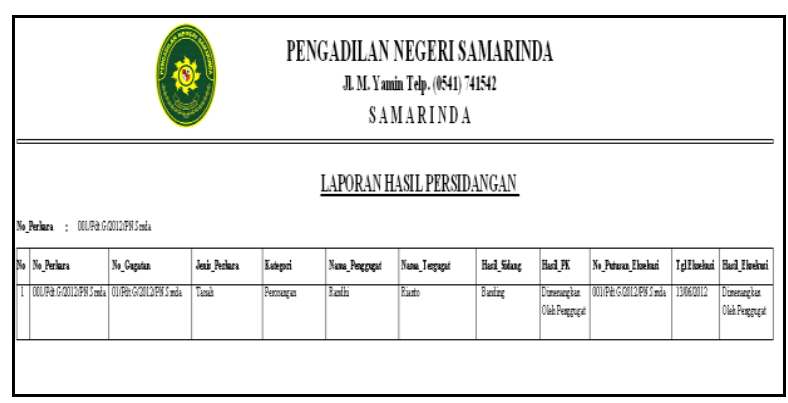

Gambar 22 Laporan Berdasarakan Nomor Perkara

Apabila user ingin melihat tampilan grafik perkara perdata perbulan klik cetak grafik laporan perkara perdata berdasarkan bulan dan tahun dan klik tombol cetak makaakan tampil seperti gambar dibawah ini

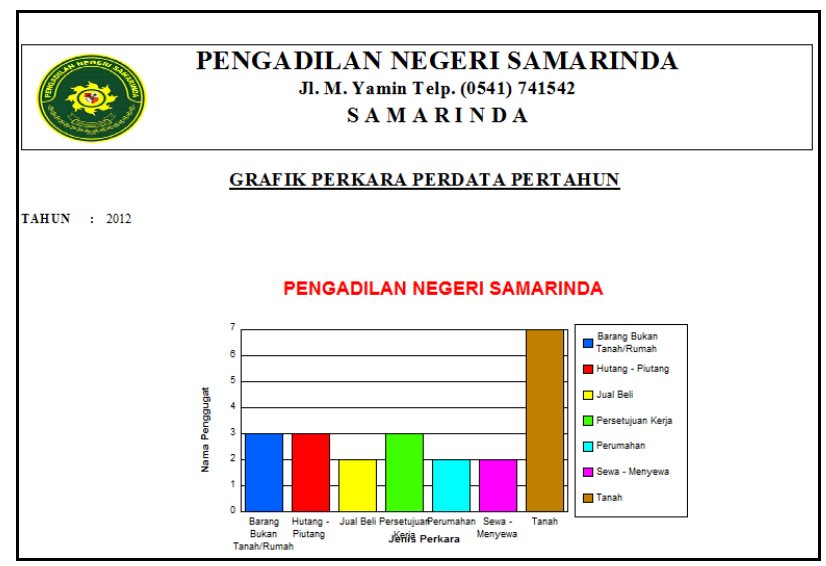

Gambar 23 Grafik perkara perdata pertahun

\subsection{Surat Putusan Pergantian Nama}

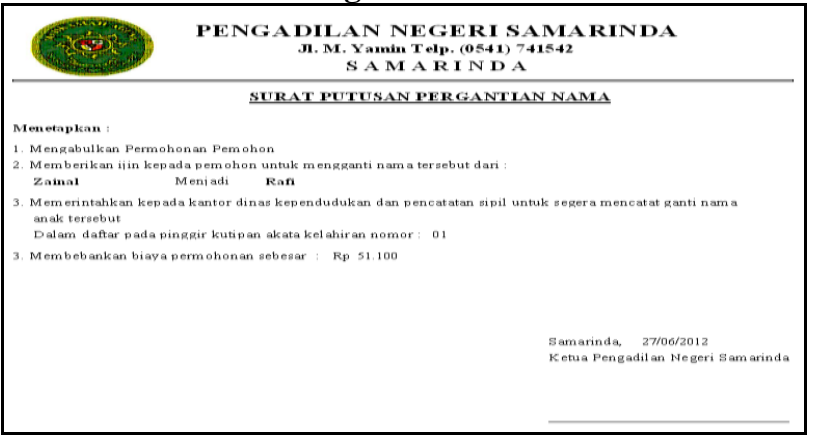

\section{Gambar 24 Surat Putusan Pergantian Nama}

Pada gambar 23 merupakan tampilan surat keputusan pergantian nama. Informasi ini diperoleh dari input data permohonan.

\subsection{Surat Putusan Pergantian Nama}

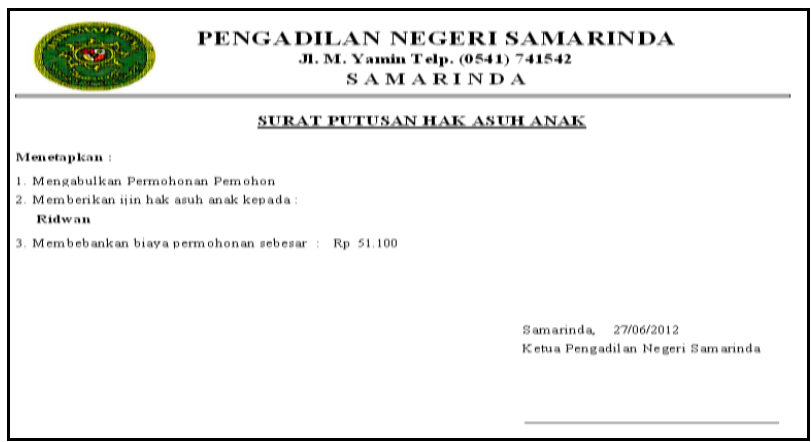

Gambar 25 Surat Putusan Hak asuh anak

Pada gambar 24 merupakan tampilan surat keputusan hak asuh anak. Informasi ini diperoleh dari input data permohonan.

\section{Kesimpulan}

Setelah penulis mengadakan penelitian pada Pengadilan Negeri Samarinda, maka penulis dapat menyimpulkan sebagai berikut :

1. Dengan adanya Sistem Informasi Pengolahan Data Perkara Perdata Pada Pengadilan Negeri Samarinda, maka dapat digunakan untuk mencatat transaksi gugatan, banding, kasasi, peninjauan kembali, dan eksekusi sehingga memudahkan dalam hal pencarian data melihat informasi perkara perdata.

2. Dengan adanya Sistem Informasi Pengolahan Data Perkara Perdata Berbasis Jaringan pada Pengadilan Negeri Samarinda dengan menggunakan pemrograman visual basic 6.0, yang sudah banyak digunakan dalam mengolah data perkara perdata.

3. Sistem yang telah dibangun dapat menampikan laporan daftar penggugat, daftar hakim, laporan perkara perdata secara keseluruhan maupun bulanan, serta grafik perkara perdata bulanan dan tahunan.

\section{Saran}

Adapun saran yang penulis berikan kepada Pengadilan Negeri Samarinda untuk perbaikan sistem adalah:

1. Agar Pengadilan Negeri Samarinda membuat koneksi jaringan komputer ke masing-masing bagian untuk memudahkan pengolahan data.

2. Agar karyawan pada bagian administrasi diberikan pengetahuan bagaimana mengoperasikan sistem informasi dan dapat menangani sendiri jika terjadi kerusakan pada sistem komputer.

3. Agar sistem ini dapat digunakan dalam jangka waktu yang lama dimana sistem ini kedepannya dapat dikembangkan berbasis web site. 


\section{DAFTAR PUSTAKA}

Ahmad M. Ramli, 2010, Tanggung Jawab Hakim Sebagai Pejabat Negara Dalam Pelaksanaan Good Governance, Jakarta.

Budi Sutedjo, 2002, Perencanaan dan Pengembangan Sistem Informasi, penerbit Andi Yogyakarta.

Janner Simarmata, 2010, Rekayasa Perangkat Lunak, penerbit Andi

Jogiyanto.HM, 2005, Analisis dan Desain Sistem Informasi, Andi Yogyakarta, Yogyakarta

Kamus Besar Bahasa Indonesia, 2001, Edisi Ketiga

Kristanto, 2003, Pengantar Sistem Informasi Manajemen, Andi Yogyakarta, Yogyakarta

Kusrini, 2007, Strategi Perancangan dan Pengelolaan Basis Data, penerbit Andi

LPKBM Madcoms Madiun, 2001, Seri Panduan Pemrograman Microsoft Visual Basic 6.0, Andi Yogyakarta, Yogyakarta

LPKBM Madcoms Madiun, 2010, Microsoft Visual Basic 6.0 dan Crystal Report, Andi Yogyakarta, Yogyakarta

Margono, 2002, Sistem Informasi Manajemen terjemahan Hendra Teguh Edisi ketujuh, penerbit Buana Ilmu Komputer, Jakarta.

Mcleod Raymon, 2001, Sistem Informasi Manajemen terjemahan Hendra Teguh Edisi ketujuh, penerbit Buana Ilmu Komputer, Jakarta.

Musthofa, 2005, Kepaniteraan Peradilan Agama, Malang.

Nana Suarna, 2007, Petunjuk Teoritis Pengantar Local Area Network (LAN), penerbit Yrama Widya, Cirebon.

Roger S. Pressman, 2002, Rekayasa Perangkat Lunak, penerbit Andi

Sudaryat, 2010, Cara Mudah Membuat Gugatan Perdata, penerbit Pustaka Yustisia, Yogyakarta

Wahana Komputer, 2009, Shortcourse Microsoft Word 2007, penerbit Andi Yogyakarta dengan Wahana Komputer, Semarang 